УДК 338.12

Сергій Галянт,

Східносвропейський національний університет імені Лесі Українки, здобувач кафедри аналітичної економіки та природокористування, м. Луцьк; e-mail: naukoviy@icloud.com

https://doi.org/10.29038/2411-4014-2019-03-99-105

\title{
ІНСТИТУЦЙНЕ СЕРЕДОВИЩЕ ВПЛИВУ МІКРО ТА МАКРО ЧИННИКІВ НА ДІЯЛЬНІСТЬ ГАЗОРОЗПОДІЛЬНИХ ПІДПРИЕМСТВ РЕГІОНУ
}

Статтю присвячено актуальним питанням інституційному забезпеченню діяльності газорозподільних підприємств, яке охоплює коло інституційних одиниць, котрі визначатимуть вектор та подальшу діяльність газорозподільних підприємств. Поміж чинників впливу на інституційне середовище мною було згруповано чинники мікроекономічного та макроекономічного характеру. Окрім того, в статті було відображено характерні риси інституційного середовища шляхом зменшення іміджу міжнародній арені, неефективній політиці, незбалансованості правового базису, що дозволить знизити монопольний тиск через реструктуризації НАН "Нафтогазу" та поширення конкурентного середовища та формування незалежного регулятора. Охарактеризовано основні інститути та установи прямого та опосередкованого впливу. Доведено, що у забезпеченні необхідного та сприятливого інституційного середовища належить органам загальної та спеціальної компетенції.

Ключові слова: інституціоналізація, інституційне середовище, газотранспортна система, газорозподільні підприємства, мікроекономічний чинник, макроекономічний чинник, мезоекономіка.

Сергей Галянт,

Восточноевропейского национального университета имени Леси Украинки, соискатель кафедры аналитической экономики и природопользования

\section{ИНСТИТУЦИОНАЛЬНАЯ СРЕДА ВЛИЯНИЯ МИКРО И МАКРО ФАКТОРОВ НА ДЕЯТЕЛЬНОСТЬ ГАЗОРАСПРЕДЕЛИТЕЛЬНЫХ ПРЕДПРИЯТИЙ РЕГИОНА}

Статья посвящена актуальным вопросам институционального обеспечения деятельности газораспределительных предприятий, которое охватывает круг институциональных единиц, которые будут определять вектор и дальнейшую деятельность газораспределительных предприятий. Между факторов влияния на институциональную среду были сгруппированы факторы микроэкономического и макроэкономического характера. Кроме того, в статье было отражено характерные черты институциональной среды путем уменьшения имиджа на международной арене, неэффективной политике, несбалансированности правового базиса, что позволит снизить монопольный давление через реструктуризацию НАК "Нафтогаза" и распространение конкурентной среды и формирования независимого регулятора. Охарактеризованы основные институты и учреждения прямого и косвенного влияния. Доказано, что обеспечениее необходимой благоприятной институциональной среды принадлежит органам общей и специальной компетенции.

Ключевые слова: институционализация, институциональная среда, газотранспортная система, газораспределительные предприятия, микроэкономический фактор, макроэкономический фактор, мезоэкономика.

Sergey Galyant,

Researcher Analytical Department of Economics and Natural Resources, Lesya Ukrainka Eastern National University

\section{INSTITUTIONAL ENVIRONMENT INFLUENCE OF MICRO AND MACRO FACTORS ON THE ACTIVITY OF GAS DISTRIBUTION ENTERPRISES OF THE REGION}

The article is devoted to the topical issues of the institutional capacity of the gas distribution companies, which covers the range of institutional units that will determine the vector and further activities of gas distribution companies. Among the factors of influence on the institutional environment, I was grouped by factors of 
microeconomic and macroeconomic character. In addition, the article reflects the characteristic features of the institutional environment by reducing the image of the international arena, the ineffectual policy, imbalance the legal basis that will reduce the monopoly pressure due to the restructuring of the NAK "Naftogaz" and the dissemination of the competitive environment and the formation of an independent regulator. The main institutions and institutions of direct and indirect influence are characterized. It is proved that in providing necessary and favorable institutional environment belongs to the bodies of general and special competence. The goal of the article is clarification of theoretical and practical approaches to institutionalizing the objects of the gas transportation sector. To achieve the goal, a number of tasks were defined: to find out the concept of "invariant environment" of gas distribution companies; Isolate factors of microeconomic and macro-economic nature of influence on the intitle environment; Predict the rectrospecative scenario of future activity of gas distribution companies in the context of gas market liberalization. Having determined the role and place of micro and macroeconomic factors to ensure the institutional environment of the operation of Gas market, it is worth highlighting a number of effects of socio-economic orientation on the environment: rational use of material and personal resources; Purpose of investment for modernization purposes; Control exchange of quality and consumption of natural gas; Operating modern business methods and tools of operational management; Compliance with environmental safety standards; Optimization of tariffs between the gas supply and the final price of gas; Harmonization of relationships between partners and consumers; development of infrastructure; Legal basis for the protection of interests of gas transportation companies; Formation of a single chain of goals: "State-gas transport sphere-consumer"; minimization of transaction expenses; Expanding the boundaries of experience in acquiring professional skills.

Keywords: institutionalization, institutional environment, gas transportation system, gas distribution companies, microeconomic factor, macroeconomic factor, mesoeconomics.

Постановка проблеми. Інституційне забезпечення організації діяльності газорозподільних підприємств охоплює коло інститутів та інституцій, котрі формують інституційне середовище та дозволяють оцінити поведінку діяльності газорозподільних підприємств, як невід'ємних своїх складових.

Інституційне середовище суб'єктів газотранспортного призначення відіграє одну 3 ключових ролей при реформуванні вітчизняного газового ринку та всієї національної газотранспортної системи.

Існуючі підходи до здійснення аналізу газорозподільчих підприємств виражають суперечливість практичних та наукових думок фахівців та спільноти 3 приводу функціонування газотранспортної системи загалом. Водночас фундаментальними причинами або запорукою успішного розвитку подій $\epsilon$ стабільне та адаптоване до сучасних реалій інституційне середовище газотранспортної сфери. Оскільки, всі суб'єкти існують та пов'язують свою діяльність 3 конкретним середовищем, яке може здійснювати прямий та опосередкований вплив на них та прийняття вірних рішень, шляхом домінування тих чи інших інституцій, тому подальше стратегічне існування даної галузі $\epsilon$ результатом розвиненості інституційного середовища. Під інституційним середовищем газотранспортної сфери прийнято розуміти діяльність певних суб'єктів, які чинять вплив на газорозподільчі підприємства через вдосконалення системи взаємозв'язків між окремими елементами та діючими суб'єктами на даному ринку. До основних ринкових елементів ринку газу прийнято відносини: конкурентне середовище, приватна власність, правовий базис, дієздатність та безперебійність інституційної структури загалом.

Аналіз останніх досліджень і публікацій. Багато знаних вчених та науковців приділили значний інтерес до теоретичних та практичних проблем та перешкод до функціонування регіональних та національних газорозподільчих підприємств, серед них: Н. Лінчевська, С. Борівець, К. Павлов, О. Павлова, М. Коротя, Н. Сарай. Стосовно інституцій та їх впливу на ефективність функціонування зазначених підприємств, чималий внесок зроблено наступними дослідниками: О. Гребешковим, О. Дзьобою, М. Данилюк, О. Амошою та іншими. Однак залишається значний масив невизначених питань інституційного вдосконалення об'єктів газотранспортної сфери та його впливу на діяльність газорозподільних підприємств, що і стало поштовхом до проведеного дослідження. Основні результати подальших розробок дали змогу сформулювати мету та завдання подальших досліджень.

Постановка завдання. Метою статті $€$ з'ясування теоретико-практичних підходів інституціоналізації об'єктів газотранспортної сфери.

Для досягнення мети було визначено ряд завдань: 
- 3'ясувати поняття “інституціональне середовище” газорозподільних підприємств;

- виокремити чинники мікроекономічного та макроекономічного характеру впливу на інституційне середовище;

- спрогнозувати ретроспективний сценарій майбутньої діяльності газорозподільних підприємств в контексті лібералізації ринку газу.

Виклад основного матеріалу. Серед чинників інституційного середовища, особливим чином важливий вплив чинять макроекономічні та мікроекономічні їх складові. Серед них, особливу увагу заслуговують чинники:

- державного організаційно-правового сектору регулювання, які проявляються у формуванні прозорого правового поля, зменшення неточностей нормативно-творчих документів, запровадження в дію інноваційних та технічних нововведень, враховуючих стратегічність дій по реструктуризації НАК «Нафтогаз». Ключовими інститутами та інституціями слід вважати Верховну Раду, Кабінет Міністрів, Президент України, Національний банк України, Державну Фіскальну Службу, Антимонопольний Комітет, Державну контрольно-ревізійну службу, Міністерство палива та енергетики, НАК «Нафтогаз України» НКРВКП, а також інші виконавчі органи, коло інтересів та діяльності яких є пов'язаними з газотранспортною сферою. вважати:

- недостатність модернізаційних заходів об’єктів ГТС, зокрема зменшення іміджу на міжнародній арені, неефективну політичну діяльність податкового, амортизаційного та кредитного напрямів, незбалансованість законодавчих документів, зниження монопольного тиску шляхом реструктуризації НАК «Нафтогаз» України та особливості створення конкурентного та незалежного регулятора на газовому ринку;

- $\quad$ моніторинг та контроль діяльності газового ринку незалежним регулятором. Складовими елементами на разі, цього чинника зовнішнього впливу виступає ринкова інфраструктура, яка чинить безпосередній вплив на відповідне інституційне середовище. Водночас, до ринкової інфраструктури слід віднести: біржі, банки, фінансово-кредитних посередників, комерційні фонди, страхові агенції, служби зайнятості, торгівельні та промислові організації.

Основними характерними рисами є:

- галопуюча інфляційна спрямованість, нерозвиненість інформаційних ресурсів, невдоволеність обслуговування фінансово-банківського сектору, незадовільна діяльність самих фінансово-кредитних, страхових та самих консультаційних установ.

- $\quad$ рівень конкурентного середовища в дотичних ринкових системах, уникнення тонізованих та лобістичних проявів, доступність суб'єктів до ринкової діяльності.

- від'ємними інституціями в напрямі прозорої конкуренції слід вважати нафтогазовидобувні підприємства, газорозподільні підприємства, інфраструктурні підприємства, промислові підприємства та інші суб'єкти товарних ринків. Невід'ємними складовими товарних ринків є на жаль, негативні явища в економічній системі, такі як: непрозорість, або навіть іноді, відсутність конкуренції на газових ринках, тривалість розробки та експлуатації газових національних родовищ; побудова нового газопроводу в обхід території України;

- ринкова кон'юнктура та створення мікроекономічного соціально-політичного середовища функціонування газових ринків. Коло інтересів охоплює громадський сектор, міжнароднопартнерський сектор, політичну атмосферу в регіоні та країні, культурно-просвітницький сектор, транснаціональні компанії. Серед притаманних ознак цього складника виділяють: відсутність достатньо етичних правил поведінки населення, відсталість від розвитку НТП, політична криза, відсутність стратегії розвитку по реконструкції i модернізації газотранспортних систем, переорієнтація частини газових потоків із РФ до країн Азіатсько-Тихоокеанського регіону; активізація зусиль країн СС щодо диверсифікації джерел та маршрутів по газопостачанню на внутрішні ринки;

- збільшення стимулювання ролі та значення, а також задіяння науково-дослідних інститутів, водночас сприяння реалізації інноваційних технологій газотранспортування. 
Основними інститутами та інституціями варто вважати: науково-дослідні установи, вищі учбові заклади, міжнародних експертів в нафтогазовій галузі. Основними та відмінними ознаками даного чинника впливу слід розуміти: достатню кваліфікацію наукових кадрів, котрі працюють в нафтогазовій галузі; низький рівень досвіду міжнародного обміну інформацією, обмеженість інноваційних розробок через низьку інвестиційну привабливість, необхідність тотальної перебудови організаційно-управлінської структури ГТП; власний газоперекачувальний потенціал, наявність необхідного нафтогазового обладнання.

Є зрозумілим, що важлива роль у забезпеченні необхідного та сприятливого інституційного середовища належить органам загальної та спеціальної компетенції. Зокрема, до органів загальної компетенції слід віднести державні структури, котрі забезпечують інституційно-правове регулювання діяльності суб'єктів газотранспортної системи, а конкретніше Верховна Рада України; Президент України; Кабінет Міністрів України. Варто відмітити, що основною з функцій організації загальної компетенції, власне і $є$ державне регулювання газотранспортної галузі. Водночас, органи спеціальної компетенції $є$ уповноваженими вирішувати всі функції, котрі забезпечують функціонування сфери енергетики та комунального господарства [1].

До них, безсумнівно слід віднести Міністерство енергетики та вугільної промисловості України та НКРЕКП.

Основною ціллю діяльності загальних та спеціальних органів компетенції $\epsilon$ розвинене інституційне середовище, яке в свою чергу виражається наявністю необхідних інститутів та інституцій, а також взаємоузгодженість між ними, що дозволить сприяти розвиненому бізнеспростору газотранспортних підприємств країни, організаційно-технічному інноваційному зростанню, збільшенню іміджу вітчизняної газотранспортної системи на міжнародній арені, покращенню якості та безпечності наданих послуг в напрямі формування лібералізованого газового ринку.

Ключовим елементом інституційного середовища $є$ інституційна координація, що спрямована на усунення невизначеності та неузгодженості прогнозів розвитку даної сфери в ретроспективному майбутньому, а також заохочення інвестиційних капіталів та забезпечення вільного доступу до мережі.

В той же час, самі інституційні одиниці, котрі чинять вплив на інституційне середовище, формуються формальними та неформальними критеріями. Перші відображаються у ряді документів, зокрема Конституцією України та іншими нормативно-правовими документами. Неформальні критерії більш ширше репрезентовані в реальному житті та включають в себе психологічні компоненти.

Формальні чинники використовуються державою для дотримання потрібного рівня розвитку підприємства прямими та непрямими інструментами. Прямі інструменти застосовуються, щоб досягти цілі економічної політики регіону та країни. За рахунок цієї політики забезпечуються конституційні права та зобов'язання громадян. Таким чином, вдається сформувати громадянське суспільство та гармонізовані соціально-економічні відносини між його суб'єктами [2].

Серед зовнішніх інститутів варто розуміти інститути мезоекономічних та макроекономічних рівнів, де саме держава є гарантом забезпечення прозорої державної політики та інституційного середовища, формуючи загальне розуміння владного галузевого менеджменту. Саме ця обставина і $\epsilon$ домінуючою у конкурентних взаємовідносинах газорозподільних підприємств на ринку газу. Цього вдається досягти шляхом використання інституційних обмежень, стимулів та дієвої форми контролю щодо механізму їх дії.

Серед більшості науковців, панує думка відносно пріоритетності інституційного підходу в подальшому успішному функціонуванні газотранспортної сфери. А інституційне регулювання діяльності суб'єктів газотранспортної системи охоплює цілеспрямовану активну діяльність останніх на розвиток та успішне функціонування вітчизняних підприємств зазначеної сфери для вдосконалення структурних елементів, відносин між ними та силу впливу на них політичних, соціальних, культурних, економічних та інших інституцій [3].

Враховуючи необхідність аналізу інституційного середовища газорозподільних підприємств особливої гостроти набуває питання аналізу організаційного аспекту їх функціонування. 
Вперше організаційні трансформації національної газотранспортної системи окреслено в Енергетичній стратегії України до 2030 року, основними з яких є:

- $\quad$ приватизаційні процеси газорозподільних підприємств та здійснення концесії;

- $\quad$ створення та участь консорціуму та Міждержавної системи газотранспортування.

Однак, вітчизняне інституційне середовище не дозволяє в повній мірі здійснити реалізацію зазначених напрямів, окрім того власнісні моменти по зміні об’єктів газотранспортного призначення характеризують здебільшого дуальну (змішану) форму.

Чимала кількість дослідників переконливо доводить про існування взаємозв'язку між складним інституційним середовищем та ймовірність ширшого використання різних форм власності на об'єкти газотранспортної та газорозподільної сфер. Водночас, їх думка є теж однозначною стосовно того, що комунальна форма власності прийнятна до використання лишень у примітивному інституційному середовищі [9].

Також не викликає жодної полеміки те, що будучи частиною природньої монополії, газорозподільні підприємства функціонують за відсутності певного конкурентного середовища у напрямі встановлення стандартів по покращенню якості, що дозволяє їм не нести відповідальності перед споживачами, не зважаючи на форму власності, в якій вони знаходяться. Тому, очевидним $\epsilon$ інституційне регулювання діяльності підприємств газотранспортної сфери задля зменшення існуючих прогалин їх функціонування у поєднанні: «держава-газорозподільне підприємствоспоживачі» [4].

Ще одним важливим кроком на шляху до вирішення інституційної незбалансованості газотранспортної сфери $є$ залучення приватного капіталу і приватизація об'єктів газопостачання. Але, на разі, це не приноситиме ефекту до тих пір, поки відсутні інструменти інституційних механізмів, які змогли би забезпечити доступність до активів, а при приватизаційних процесах, була б посилена роль лобіювання приватних інтересів, неефективність правових рішень, закритість даних та високі трансакційні витрати [8].

Очевидною обставиною $є$ також, без сумніву поява хаотичних контрактних взаємовідносин між споживачами та постачальниками газу, відсутність достатніх мотиваційних стимулів до відповідальності перед споживачами при неякісному та незбалансованому інституційному середовищі. Тому створення інституційних механізмів самоконтролю дозволить підвищити результативність діяльності газорозподільних підприємств, покращить якість газу та газотранспортних послуг, стимулювавши суб'єктів ринку до енергозбереження, раціонального та ощадливого використання ресурсів та дотримання екодопустимого балансу навколишнього середовища [5].

Економічний підхід теж проявляється в інституалізації, оскільки віднесення газотранспортних підприємств до вертикально-інтегрованої структури відповідно до інституційної теорії, формує високі трансакційні витрати, а наявність інформаційних осередків дає можливість деструкції інформаційного узгодження між інституціями загалом. Обмежена раціональність та безвідповідальна поведінка по обидва боки вертикалі провокують виникнення тіньових схем, що є частим явищем для даних структур [6].

Серед інституційного забезпечення виділяють і мікроекономічну інституційну будову, зокрема, ресурсне забезпечення підприємств газотранспортної сфери значно ускладняється ієрархічною будовою НАН «Нафтогаз України». На разі організаційна структура характеризується відсутністю передових технологій та інновацій, недостатністю інвестиційних вкладів, неправомірною правовою оцінкою проведення закупівельних процедур, обмеженістю альтернативностей взаємозв'язків між суб'єктами українського інституційного середовища [7].

Висновки. Визначивши роль та місце мікро та макроекономічних чинників на забезпеченні інституціонального середовища функціонування ринку газу, варто виділити ряд ефектів соціальноекономічного впливу на середовище:

- раціональне використання матеріальних та особистих ресурсів;

- цільове призначення інвестицій на модернізаційні цілі;

- $\quad$ контролювання обміну якості та споживання природного газу;

- оперування сучасними бізнес-методами та інструментами оперативного менеджменту;

- дотримання норм екологічної безпеки; 
- $\quad$ оптимізація тарифів між газопостачанням та кінцевою ціною газу;

- гармонізація взаємостосунків між партнерами та споживачами;

- розвиненість інфраструктури;

- $\quad$ нормативно-правовий базис, щодо захисту інтересів газотранспортних підприємств;

- формування єдиного ланцюгу цілей: «держава-газотранспортна сфера-споживач»;

- мінімізація трансакційних витрат;

- $\quad$ розширення меж досвіду набуття професійних навичок персоналом.

Отже, слід зробити висновок, що важливими мікро та макроекономічними чинниками ефективності функціонування системи транспортування природного газу є наявність та дієвість усіх необхідних інститутів, які формують ефективне інституційне середовище.

\section{Джерела та література}

1. Актуальні проблеми прикладної економіки: [кол. моногр.] / за заг. ред. д-ра екон. наук, проф О.М. Стрішенець. Луцьк. 156 с.

2. Гребешков О.М. Інформаційне забезпечення розвитку підприємства: аналітична оцінка зарубіжної та вітчизняної практики. Формування ринкової економіки. 23. 2010. С.177-189.

3. Про утворення Національної акціонерної компанії "Нафтогаз України". Постанова Кабінету Міністрів. 25 травня 1998. 747. URL: https://zakon.rada.gov.ua/laws/show/747-98-\%D0\%BF. (дата звернення 20.08.2019).

4. Коротя М. I. Етапи становлення нафтогазової промисловості в Україні. Економічний часопис Східноєвропейського національного університету імені Лесі Украӥнки. Луцьк. 2017. 1(9). С. $76-81$.

5. Лінчевська Н.М., Дзьоба О.Г. Аналіз чинників та організаційно-економічних інструментів забезпечення інноваційного розвитку газотранспортних підприємств. Науковий вісник Івано-Франківського національного технічного університету нафти $i$ газу. Серія «Економіка та управління в нафтовій $i$ газовій промисловості». 2014. 1(9). С. 47-55.

6. Павлов К. В., Шевчук І.Л. Інноваційні фінансово-кредитні важелі як складова ефективної антимонопольної політики. Науковий вісник Ужсгородського університету. Серія «Економічна». 2018. 51. C. $72-74$.

7. Стрішенець О. М., Новосад О.В. Особливості функціонування інновацій в діяльності газорозподільних підприємств. Актуальні проблеми управління соиіально-економічними системами: матеріали Міжнар. наук. практ. інтернет-конф., 7 груд. 2017. 1(9). Луцьк. 2017. С.162-163.

8. Фінансові результати 2016 року ПАТ «Волиньгаз». URL: https://vl.104.ua/ua/files/22590/1. (дата звернення 20.08.2019).

9. Про заходи щодо реалізації державної політики у сфері природних монополій. Постанова Кабінету Міністрів України. 16 грудня 1996. 853/97. URL: https://zakon.rada.gov.ua/laws/show/853/97. (дата звернення 20.08.2019).

\section{References}

1. Aktualni problemy prykladnoi ekonomiky. (2017) [Actual problems of applied economy]. O.M. Strishenets (Ed.). Lutsk: Vezha-Druk. [in Ukrainian].

2. O.M. Hrebeshkov (2010). Informatsiine zabezpechennia rozvytku pidpryiemstva: analitychna otsinka zarubizhnoi ta vitchyznianoi praktyky [Information support of enterprise development: analytical evaluation of foreign and domestic practice]. Formuvannia rynkovoi ekonomiky- Formation of market economy. (23nd.). Kyiv: KNEU [in Ukrainian].

3. Zakon Ukrainy "Pro utvorennia Natsionalnoi aktsionernoi kompanii "Naftohaz Ukrainy": pryiniatyi 25 travnia 1998 roku № 747. [Law of Ukraine on formation of Naftogaz of Ukraine Joint Stock Company from May 25 1998 № 747]. Retrieved from https://zakon.rada.gov.ua/laws/show/747-98-\%D0\%BF [in Ukrainian].

4. M.I. Korotya, (2017). Etapi stanovlennya naftogazovoyi promislovosti v Ukrayini [Stages of the formation of the oil and gas industry in Ukraine]. Economic Journal of Lesya Ukrainka East-European National University. 1 (9), (pp. 76-81). Zhurnal Lutsk : Vezha-Druk [in Ukrainian].

5. N.M. Linchevska, O.H. Dzoba. (2014). Analiz chynnykiv ta orhanizatsiyno-ekonomichnykh instrumentiv zabezpechennia innovatsiynoho rozvytku hazotransportnykh pidpryiemstv [Analysis of factors and organizational and economic instruments for ensuring innovative development of gas transportation entrprises]. Naukovy visnyk Ivano-Frankivskoho natsionalnoho tekhnichnoho universytetu nafty $i$ hazu. Seriia «Ekonomika ta upavlinia $v$ naftovyi hazoviy promyslovosti»-Scientific Bulletin of the Ivano-Frankivsk 
National Technical University of Oil and Gas. Series "Economics and Management in the Oil and Gas Industry", 1(9), 47-55 [ in Ukrainian].

6. K. V. Pavlov, I. L. Shevchuk. (2018). Innovatsiini finansovo-kredytni vazheli yak skladova efektyvnoi antymonopolnoi polityky [Innovative financial leverage as part of an effective antitrust policy]. Naukovyi visnyk Uzhhorodskoho universytetu-Uzhgorod University Scientific Bulletin, 51, 72-74. [in Ukrainian].

7. I. M. Strishenets, O. V. Novosad (2017). Osoblyvosti funtsionuvannia innovatsiy v diialnosti hazorozpodilnykh pidpryiemstv [Features of functioning of innovations in activity of gas-distributing enterprises]. Aktualni problemy upravlinnia sotsialno-ekonomichnymy systemamy- Actual problems of management of socioeconomic systems. Proceedings from: International Scientific and Practical Conference, 1(9), (pp. 162-163). Lutsk: RVV Lutskoho NTU [in Ukrainian].

8. Finansovi rezultaty 2016 roku PAT «Volynhaz» [Financial Results of 2016 Volyngaz PJSC]. Retrieved from https://vl.104.ua/ua/files/22590/1 [in Ukrainian].

9. Zakon Ukrainy "Pro zakhody shchodo realizatsii derzhavnoi polityky u sferi pryrodnykh monopolii" pryiniatyi 16 hrudnia 1996 roku №853/97 [Law of Ukraine on measures to implement state policy in the field of natural monopolies from December 161996 №853/97. Retrieved from https://zakon.rada.gov.ua/laws/show/853 / 97 [in Ukrainian].

Стаття надійшла до редакції 28.06.2019 р.

УДК: 338.2

Купчак Володимир, доктор економічних наук, доцент,

Східноєвропейський національний університет імені Лесі Українки, кафедра аналітичної економіки та природокористування, м. Луцьк; e-mail: kupchak@me.com

Павлова Олена, доктор економічних наук, професор, Східносвропейський національний університет імені Лесі Українки, завідувач кафедри аналітичної економіки та природокористування, м. Луцьк; ORCID ID: 0000-0002-8696-5641 e-mail: pavlova.olena@eenu.edu.ua

Павлов Костянтин, доктор економічних наук, доцент, Східноєвропейський національний університет імені Лесі Українки, кафедра аналітичної економіки та природокористування, м. Луцьк; ORCID ID: 0000-0003-2583-9593 e-mail: pavlovkv@icloud.com

Червеняк Вікторія, студентка,

Східносвропейського національного університету імені Лесі Українки, кафедра аналітичної економіки та природокористування м. Луцьк

https://doi.org/10.29038/2411-4014-2019-03-105-112

\section{ФУНКЦІОНУВАННЯ МЕРЕЖІ ПІДЗЕМНИХ ГАЗОВИХ СХОВИЩ В КОНТЕКСТІ ЕНЕРГЕТИЧНОЇ БЕЗПЕКИ КРАЇНИ}

В даній статті було досліджено особливості функціонування підземної мережі газових сховищ України в контексті енергетичної безпеки. Окреслено організаційно-економічний базис енергетичної безпеки держави на 